\title{
A Historical Approach to Alcohol Abuse
}

\author{
Afërdita Nikaj ${ }^{1}$ and Gentian Vyshka ${ }^{2, *}$
}

${ }^{1}$ Faculty of Medical and Technical Sciences, University of Medicine in Tirana, Albania

${ }^{2}$ Department of Physiology and Pharmacology, Faculty of Medicine, University of Medicine in Tirana, Albania

\begin{abstract}
Alcohol consuming is so present in human history to the extent that it has become 'a universal language'. Under this point of view, studying historical trends regarding alcohol consume, geographical profile of its abuse, political approaches at the level of public health in different countries and epochs, might be of interest toward understanding the actual situation. Alcohol beverages have been considered positively due to the unproven belief that they have curative and medicinal characteristics. The oldest recipe describing the way of preparing an alcoholic drink is for the beer, dating more than 3800 years before, written over a stone plaque. The entire text is a hymn for Ninkasi, the Sumerian goddess of beer. Other authors suggest that wine has been part of the menu since six millennia, with archeological uncovering of Hajji Firuz Neolithic house that yielded the six wine jars in Tepe, ancient Persia. Different options have been tested with the aim of controlling the production and trading of these beverages, with all advantages and disadvantages that these implemented options present.
\end{abstract}

Keywords: Alcohol, chronic alcoholism, public health, historical trend, prohibitionism.

\section{INTRODUCTION}

Alcohol consuming is so present in human history to the extent that Patrick Mc-Govern, a chemical archeologist at the University of Pennsylvania calls it 'a universal language' [1]. Under this point of view, the study of historical trends regarding alcohol consume, geographical profile of its abuse, political approaches at the level of public health in different countries and epochs, might be of interest toward understanding the actual situation, as well as the respective tools for dealing with problems that alcohol abuse will cause.

Historical trends do have their own importance. Authors believe that in most of European and NorthAmerican territories alcohol consumption has been much more consistent during the XIX century, thus if we think we're exceeding in drinking our predecessors, that might be wrong [2]. Beer might have been the main ethanol source, although gradually its importance relative to spirits and wine has declined [3].

The effects of globalization have become touchable even in the alcohol consumption. An increase in alcohol beverages consumption has been registered after WWII and that trend lasted till the seventies of the last century; these fluctuations are hardly explainable through a single effect or factor, such as might be economic differences, cultural backgrounds, upcoming industrialization, forced urbanization and other social factors. A mixture of the latter, in fact, might be the determining element in a certain place and time.

*Address correspondence to these authors at the Department of Physiology and Pharmacology, Faculty of Medicine, University of Medicine in Tirana, Albania; Tel: +35542362268; Fax: +355692828140;

E-mail: gvyshka@yahoo.com
The prehistory of alcohol beverages followed the simple observation of the natural fermentation of fruits. Under the effect of yeast sugar was turned into alcohol, without any need for special advertising from (at that time) inexistent ethanol industry and humans tasted and consumed it freely. Everything fermentable (fruits, berries, flowers, honey, milk, corn, barley, wheat, sugar cane and so on) was found to potentially produce alcohol, and local agriculture naturally selected the characteristics of the drinking that would become familiar to a certain geographical area [4]. Later on Arabs invented distillation, and exported such a technique in Europe. That was in the sixth century, and worth mentioning is even that alcohol derives from the Arabic al-kouhoul [5]. This finding, together with the archeological uncovering of Hajji Firuz Neolithic house that yielded the six wine jars in Tepe, ancient Persia, shows us how peculiar history itself might be $[6,7]$. In fact, actually all these territories (Arabic countries and Iran) are much more sober when compared to Europeans when it comes to alcohol consumption, with local policies close to a total prohibitionism, although usage and even dependence has been reported even here [8]. Asian countries will obviously present no exclusion from this global rule [9].

After all, this means that alcohol and alcohol-related problems, apart from regional, cultural and religious influences, are intrinsically related within human nature. 'The universal language' will therefore, require a universal approach, and a globally available explanation.

\section{BELIEFS AND MISBELIEVES}

Alcohol beverages have been considered positively due to the unproven belief that they have curative and 
medicinal characteristics. The oldest recipe describing the way of preparing an alcoholic drink is for the beer, dating more than 3800 years before, written over a stone plaque. The entire text is a hymn for Ninkasi, the Sumerian goddess of beer.

Initially considered as a miracle drug, able to improve mood, sexual performance or life quality in general, alcohol very soon became a disappointing factor toward its overt inability to make only but the contrary of what the pagans believed. However, the myth of alcohol was already impregnated in the everyday language, long time before liver specialists correlated its abuse with cirrhosis; and well before Wernicke and Korsakoff described the notorious nervous conditions following binges [10-13].

Scottish Gaelic started calling their miraculous beverage as uisge beatha, the actual famous whiskey. This two words, whose meaning is water of life, were verbatim borrowed and used from Latin peoples in acquavitae, actually the equivalent of grappa; although wine has ever since been of predilection in all the Mediterranean area. In fact, wine is the most quoted beverage in the Biblical texts and exegesis, with Noah establishing a vineyard soon after surviving the apocalyptical flood [14].

Wine and drinking in general has found plenty of space in literature, paintings and arts as well. A catholic poet like Dante Alighieri still maximizes his belief in solar deities and esteems drinking of wine, in verses like 'guarda il calor del sole che si fa vino' ("look at the warmth of the sun becoming wine") [15]. Shakespeare is more objective and pitiless, when making clear to the reader that drinking provokes '... nose-painting, sleep and urine. Lechery... provokes, and unprovokes; it provokes the desire, but it takes away the performance' [16]. Yet another poet, whose affinity for drinking leaves no historical doubts, gives precise advice how to avoid binges and intoxication. In fact, Goethe suggests mixing wine with water. This is a very old custom, since Romans considered drinking crude wine an action of barbaric origin. The receipt of Goethe is extremely laconic and still valuable [17]:

"Wasser allein macht stumm,

das beweisen im Teiche die Fische,

Wein allein macht dumm,

das beweisen die Herren am Tische, weil ich nun keines von beiden will sein,

trinke ich Wasser vermischt mit Wein". ${ }^{1}$

Of course, in between all discussions, artistic, scientific, or religious be there in nature, the question of whether alcohol makes more good than harm, still remains unresolved. Unresolved of course is the fact, more precisely the amount, of how much alcohol is acceptable, why not advisable, for the human health. A matter of long-term controversy, medical authorities have tried to reach a conclusion. Anstie's alcohol limit is one of those deserving to be quoted even one and half century after the author - a famous physician of the epoch - formulated it [18, 19]. Francis E. Anstie, the editor of Practitioner and a constant contributor to The Lancet, suggested that a pint of light wine (approximately 0.6 liters), or the equivalent of it (in terms of ethanol percentage), was the maximum amount of absolute alcohol taken daily without injury.

If these formulas, including the ad hoc remix of Goethe, are still of value, is still a matter of controversy, like the Anstie's amount of alcohol limit.

\section{PROHIBITIONISM AND ITS REPEALERS}

With the actual extent of alcohol consumption it might be even hard to understand how an immense country like America could pass a bill to completely block the production and the trade of alcohol beverages.

However, that became reality, but obviously not in a single day. The prohibitionist movement had its increasing peak at the end of nineteenth century, especially after that the Anti-Saloon League was founded [20]. Panoply of social and political reasons pushed forward the American legislative power to adopt the famous $18^{\text {th }}$ Amendment, with a special bill stopping completely the production, the selling and the transporting of beverages exceeding a content of $0,5 \%$ of alcohol. That lasted from 1919 till 1933, a period during which counterfeited beverages and contraband of liquors was flourishing.

One might think of prohibitionism as a mere American phenomenon, which is not. Interestingly enough, almost during the same period of time, Norway

\footnotetext{
'Water alone makes you mute / as proven by the fish in the pond / wine alone makes you stupid / as proven by the men around the table / since I do not want to be either / I drink water mixed with wine".
} 
prohibited the sale of distilled spirits from 1916 to 1926 , and fortified wines were banned from 1917 to 1923 [21].

Anti-Saloon League was founded in 1893, with a strong support from Christian Union of Women. Both these social movements were in fact mirroring the excessive amount of alcohol consumption in USA of the time, with all public health, social and economic consequences. Temperance and staying dry was on the other hand considered a patriotic act, with the country trying to overcome the aftermath of the First World War. Anyway, since other countries (like Norway) adopted almost the same policies during that period, explaining the fact merely in post-war terms would be a simplifying position.

The only way to find and consume alcoholics during prohibitionism was through medical prescriptions, and therefore only in pharmacies. The sacramental use of wine during mess celebration was still permitted. In his "The City of Chicago: A Study of the Great Immoralities" George Kibbe Turner describes the situation as follows [22]:

"There are 7300 licensed liquor sellers in Chicago and in addition about a thousand places where liquor is sold illegally. The only business which approaches this in number of establishments, according to the Chicago directory, is the grocery trade, which has about 5,200. The city spends at least half as much for what it drinks as for what it eats not counting the cost of the cooking and serving of food..."

Prohibitionism lasted not longer than fifteen years, but that was not mainly because its repealers overcome the temperance advocates. It merely didn't work, and the new American generation refused to make another more sacrifice; and probably this trend was global. Other authors have tried to formulate much more complex theories behind the failure of prohibition, going so far to say that there was "a massive Wall Street conspiracy to reduce taxes on the rich and bring back beer, 'a narcotic with which it is planned to etherize radical movements" [23]. The latter still remains a bitter explanation, however.

\section{CONCLUSIONS}

Humankind seems to well know all issues related to alcohol abuse, and very complicated therapeutic schema have been implemented to treat alcohol addiction and dependence. Anstie's limit (more than half a liter of wine) has fallen to more than one third of what the author proposed initially, and still the protective role in terms of cardiovascular disease, of small doses of alcohol, is controversial. In the contrary, the fatty heart has been related to alcohol since Victorian times [24].

When little doubt is left on the role of ethanol as the solely factor responsible for addiction, carencial disorders, physical dependence, acute and chronic intoxication, discussions have been made if there might be another active principle acting or co-acting in the process of intoxication. The myth of thujone, a constituent of absinthe, probably resisted much longer than expected; yet actually is clear that even absinthism is nothing more than a type of alcoholism [25].

With alcohol always present in all menus, restaurants and lounges, a constant need to control the total consumed amount has been a challenge to all public health policies. System Bolaget, a government owned chain of liquor stores in Sweden, seems a very well organized approach. Its philosophy of restricting alcohol consumption is not merely based in raising prices, but through limiting availability as well; organizers self-appraise, in a convincing way, their efficacy [26]. Physicians will do the rest; when it is not too late.

\section{REFERENCES}

[1] Uncorking the past: The history of drinking. The Economist Dec. $20^{\text {th }}, 2001$. [Available at: http://www.economist.com/ node/883706. (Last accessed Oct. 17 $7^{\text {th }}, 2013$ )]

[2] Three centuries of British drinking. Br Med J 1978; 1(6124): 1373.

http://dx.doi.org/10.1136/bmj.1.6124.1373

[3] Spring JA, Buss DH. Three centuries of alcohol in the British diet. Nature 1977; 270(5638): 567-72. http://dx.doi.org/10.1038/270567a0

[4] Hirsh J. Historical perspectives of the problem of alcoholism Bull N Y Acad Med 1953; 29(12): 961-71.

[5] The arak of choice. The Economist, January 2004. [Available at: http://www.massaya.com/arak.pdf. (Last accessed Dec. $\left.\left.12^{\text {nd }}, 2013\right)\right]$.

[6] http://www.penn.museum/sites/wine/wineneolithic.html. (Last accessed Dec. 17 $7^{\text {th }}, 2013$ ).

[7] http://www.cais-soas.com/CAIS/Culture/wine good.htm (Last accessed Nov. 28 ${ }^{\text {th }}, 2013$ ).

[8] AlMarri TS, Oei TP. Alcohol and substance use in the Arabian Gulf region: a review. Int J Psychol 2009; 44(3): 22233.

http://dx.doi.org/10.1080/00207590801888752

[9] Liu Q, Lawrence AJ, Liang JH. Traditional Chinese medicine for treatment of alcoholism: from ancient to modern. Am J Chin Med 2011; 39(1): 1-13. http://dx.doi.org/10.1142/S0192415X11008609 
[10] Wernicke C. Lehrbuch der Gehirnkrankheiten fur Ärzte und Studirende. Kassel Theodor Fischer 1881; Vol 2: 229-242.

[11] Thomson AD, Cook CC, Guerrini I, Sheedy D, Harper C, Marshall EJ. Wernicke's encephalopathy revisited. Translation of the case history section of the original manuscript by Carl Wernicke 'Lehrbuch der Gehirnkrankheiten fur Ärzte and Studirende' (1881) with a commentary. Alcohol Alcohol 2008; 43(2): 174-9. http://dx.doi.org/10.1093/alcalc/agm144

[12] Korsakoff SS. Eine psychische Störung combiniert mit multipler Neuritis (Psychosis polyneuritica seu Cerebropathia psychica toxaemica). Allgem Zschr Psychiatr 1890; 46: 475485.

[13] Vein A. Sergey Sergeevich Korsakov (1854-1900). J Neurol 2009; 256(10): 1782-3. http://dx.doi.org/10.1007/s00415-009-5289-x

[14] Soleas GJ, Diamandis EP, Goldberg DM. Wine as a biological fluid: history, production, and role in disease prevention. J Clin Lab Anal 1997; 11(5): 287-13. http://dx.doi.org/10.1002/(SICI)10982825(1997) 11:5<287::AID-JCLA6>3.0.CO:2-4

[15] Alighieri D. La Divina Commedia; Purgatorio (Canto XXV); Verses 76-78. [Available at: http://www.edicolaweb.net/ nonsoloufo/pur25.htm. (Last accessed Dec. 25 $\left.\left.{ }^{\text {th }}, 2013\right)\right]$.

[16] Shakespeare W. Macbeth, Act 2, Scene 3; Verses 28-36. [Available at: http://www.shakespeare-navigators.com/ macbeth/T23.html. (Last accessed Dec. 25 $\left.{ }^{\text {th }}, 2013\right)$ ].

[17] Goethe JW. Aphorisms. [Available at: http://www. aphorismen.de/gedicht/65997 (Last accessed Nov. 28 ${ }^{\text {th }}$, 2013)].
[18] Baldwin AD. Anstie's alcohol limit: Francis Edmund Anstie 1833-1874. Am J Public Health 1977; 67(7): 679-81.

[19] Babor TF, Kranzler HR, Lauerman RJ. Social drinking as a health and psychosocial risk factor. Anstie's limit revisited. Recent Dev Alcohol 1987; 5: 373-402.

[20] http://prohibition.osu.edu/anti-saloon-league/dry-propaganda (Last accessed Dec. 26 ${ }^{\text {th }}, 2013$ ).

[21] Hem PE, Hem E. Regulations with plenty of loopholes--the doctors' prescription rights during the era of prohibition 19161926. Tidsskr Nor Laegeforen 2012; 132(23-24): 2636-40.

[22] Turner GK. The City of Chicago: A Study of the Great Immoralities. McClure's Magazine 1907; 28: 575-592. [Available at: http://www.brocku.ca/MeadProject/Turner/ Turner_1907.html. (Last accessed Dec. 26th, 2013)].

[23] Gordon E. The wrecking of the Eighteenth Amendment. Francestown, N. H.: Alcohol Information Press, 1943; 98107.

[24] Bedford E. The story of fatty heart. A disease of Victorian times. Br Heart J 1972; 34(1): 23-8.

[25] Lachenmeier DW. Absinth - Geschichte einer Thujon- oder Alkoholabhängigkeit? Fortschr Neurol Psychiat 2007; 75: 306-308.

[26] http://www.systembolaget.se/ImageVaultFiles/id_18970/cf_3 64/eng_ansvarsredo_2011.PDF. (Last accessed Dec. 23 ${ }^{\text {rd }}$, 2013).

\section{DOI: http://dx.doi.org/10.14205/2310-4007.2013.01.02.4}

(C) 2013 Nikaj and Vyshka; Licensee Pharma Professional Services.

This is an open access article licensed under the terms of the Creative Commons Attribution Non-Commercial License (http://creativecommons.org/licenses/by-nc/3.0/) which permits unrestricted, non-commercial use, distribution and reproduction in any medium, provided the work is properly cited. 